This is the authors' post-print PDF version

of the paper 'Where all the rivers flow west: Maps, abstraction and change in the Papua New Guinea lowlands' published in 2014 in The Australian Journal of Anthropology.

Citation details for the published version are:

Dwyer, P.D. \& M. Minnegal (2014) Where all the rivers flow west: Maps, abstraction and change in the Papua New Guinea lowlands. The Australian Journal of Anthropology 25: 37-53.

\title{
Where all the Rivers Flow West: Maps, Abstraction and Change in the Papua New Guinea Lowlands
}

\author{
Peter D. Dwyer ${ }^{1}$ and Monica Minnegal ${ }^{2}$ \\ 1. School of Land and Environment, The University of Melbourne \\ 2. School of Social and Political Science, The University of Melbourne
}

\begin{abstract}
'Abstraction' has been often identified as a key element in social change. Analyses, however, have often conflated the ideas of abstraction as 'object' and as 'process'. This paper discusses two maps drawn by or on behalf of Kubo men, of the interior lowlands of southern Papua New Guinea. They were drawn in the context of recent exposure to a vast Liquefied Natural Gas project initiated on the land of their neighbours and both, as abstractions from new observations and experiences, were intended as assertions of rights to land. They derived, however, from entirely different logics: one more compatible with 'Western' understandings of ownership, the other more in keeping with earlier Kubo understandings of belonging. By reference to these maps, we consider the role of abstraction in social change and argue that while, as object, abstraction is relative as a process it is universal.
\end{abstract}




\section{INTRODUCTION}

Social change is often represented, either explicitly or by implication, as entailing a shift from more concrete to more abstract representations and understandings of the lived world. Wilden (1972), for example, writes of shifts from analogical to digital logical types; Wagner (1977) of shifts from figurative to literal symbolic expressions, Dwyer and Minnegal (2010) of shifts from relational to categorical epistemologies, Giddens (1990) of a process of disembedding and Hornborg (1996: 45) emphasizes the role of 'abstract, totalising systems such as science or the market'. There is often a sense in such analyses that less abstracted social relations are being replaced by more abstracted ones, an implication that loses sight of the fact that the supposedly concrete and the supposedly abstract are 'entangled in a dynamic coexistence' (Stead 2012: 233). There may be, in addition, a conflation of product and process such that a temporal sequence of products - a history - is mistakenly assumed to reveal the process that underwrites that history, and a failure to recognise that abstraction as product (or object), though not as process, is itself relative to both the actor and observer. While abstraction is indeed implicated in social change, the reconfiguration of meanings it enables will take diverse forms.

In this paper we explore abstraction both as object and as process. Our particular concern is with social change in a context of global impacts on local life styles and understandings. We ground our analysis by reference to two maps held by Kubo people of the interior lowlands of Papua New Guinea. One map was drawn by an outsider on behalf of a Kubo man and under his instruction with respect to content. The second was drawn by a few Kubo men without outside help. Both were drawn in the context of the presence of a mining company that, from 2006 to 2009, used an airstrip on Kubo land as a base for operations while establishing infrastructure for a major part of an AUD\$19 billion Liquefied Natural Gas project on the land of Febi people who were neighbours to Kubo (Ernst 2008, Goldman 2009, Gouy et al. 2010, Hydrocarbons-technology.com. 2012, McIlraith et al. 2012). Both maps were drawn as assertions of rights to land and of rights to imagined benefits that would flow when, one day, exploitable resources oil, gas, minerals or timber - were discovered on Kubo land. They were, however, underlain by very different understandings of land and ownership and each of them, though in different ways, gave material expression to the subtleties of thought and agency that underwrote the desire for, and the process of, change (Bell 2009, Dwyer and Minnegal 2010).

After providing background information on Kubo we describe the two maps, comment briefly on the way in which locally produced maps and other documents express desires for recognition and empowerment and then, drawing on those descriptions and with particular reference to change, discuss abstraction, first, as object and, secondly, as process.

\section{BACKGROUND}

Kubo people comprise a language group living immediately south of the Blucher and Muller Rangers, in the interior lowlands of the Western Province of Papua New Guinea (Dwyer and Minnegal 1992; Fig. 1). They were, and for the most part remain, hunter- 
horticulturalists whose subsistence is based, primarily, on bananas, sago flour, fish and large game (pigs and cassowaries) and, in the past decade, sweet potato. They keep domestic pigs though the sires of all of these are wild animals. Until the 1970s they had little contact with either colonial officers or missionaries but, after that time, progressively shifted from longhouse to village-based residence.

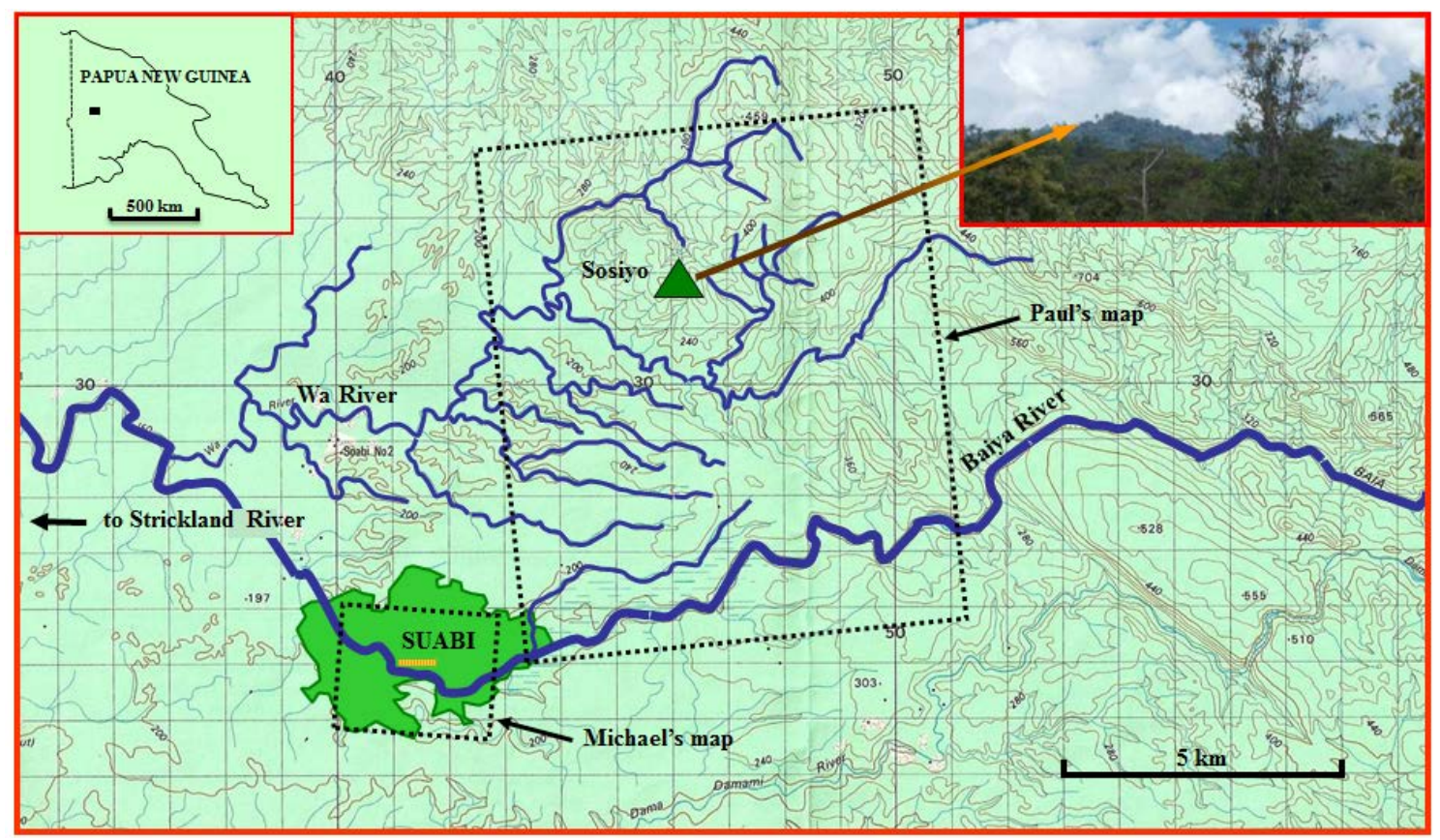

Fig. 1: Topographic map showing location of Suabi. The airstrip, primary rivers, a resting place of the spirits of the dead (the mountain Sosiyo), and the area of secondary growth (shaded uniformly) around Suabi in 2011 have been highlighted. The two 'boxes' enclose the areas depicted in the two maps discussed in this paper. They are indicative only; the actual areas are not rectangular. The insets show mainland Papua New Guinea, on the left, and Sosiyo on the right. The map is a portion of the PNG 1:100,000 Topographic Survey, Sheet 7385 (edition 1) Series T601, Printed 1979. The area marked as secondary growth has been traced from a satellite image (Google maps, (c) 2011, accessed 2 January 2012).

Our own work among Kubo commenced in 1986, continued to 1999 and recommenced in 2011. In the years to 1999 we were based at the small village of Gwaimasi (= Komagato) on the west bank of the Strickland River. Since 2011 we have been based at Suabi ( $6^{\circ} 06^{\prime} \mathrm{S}, 142^{\circ} 16^{\prime} \mathrm{E}$, altitude $134 \mathrm{~m}$ ASL), an amalgam of five some people would say seven - 'clusters' of houses located north and south of the Baiya (= Boye or Cecelia) River. Since the mid-1980s, Kubo population size has doubled from approximately 500 to around 1000 and average population density has increased from approximately 0.5 to 1.0 persons per square kilometre. Sedentization has increased, mortality of infants and the elderly has been dramatically reduced, initiation and séances have ceased, and marriage practices have shifted from an ideal of immediate sister exchange to a mix of, often delayed, exchange and bride wealth. There remains, however, an abiding concern with sorcery. 
In the years from 1986 to 1999 we observed a gradual shift from a relational to a categorical epistemology such that women, pigs and land were, increasingly, spoken of in categorical terms (Dwyer and Minnegal 1998, 2010; Minnegal and Dwyer 1997). This shift emerged not in response to direct engagement with outsiders but, rather, in response to rumours about what the outside world offered and expected. Nor by 1999 had it run to completion. It was simply that, by 1999, there were strong elements of categorization where, formerly, Kubo life-ways were ordered primarily in terms of relationships between people, between people and land and between people and the spirit beings that dwelled in the land.

Suabi was established as an Evangelical Church of Papua New Guinea mission station in the early 1980s and, until the early 2000s, was home to missionaries from the United States of America. An airstrip was completed in 1984, a community health centre opened at about the same time and a primary school in 1987. The school, however, has had a chequered history and since 2010 there has been only an Elementary School that provides the first two years of education. Until the mid-2000s the only impact from mining companies came from relatively short-term exploration on Kubo land or the lands of their neighbours. This changed in 2006, when a long-term base was established around the airstrip to service installation of infrastructure for the Liquefied Natural Gas project approximately $30 \mathrm{~km}$ north of Suabi on the land of Febi people (Ernst 2008). This facility was abandoned late in 2009 after preliminary Benefit Sharing Agreements had been signed with some stakeholders. Many Febi people live at Suabi. Some came from the north at the time the mission was established, others came so that their children could attend school and more continue to arrive - at least to visit for extended periods - in the expectation that proximity to airstrip and radio will open opportunities that are not available on their own lands.

Through the years 2006 to 2009 many men and some women were employed by the Liquefied Natural Gas project. This tangible presence, together with a great increase in access to money, accelerated change. Young men and women attended high schools at Kiunga or in the Highlands, marriages occurred with people from distant places, men visited Port Moresby, facility in both Pidgin and English became widespread and categorical understandings of the world were enhanced. Through this period too, Kubo people became increasingly aware of procedures entailed in social mapping, the establishment elsewhere of 'incorporated land groups' (ILGs) and the potential for realising 'benefits' from these 'tools of modernity' by producing documents modelled on those which they had seen or been told about. The two maps that provide the empirical basis for our analysis were produced with an eye to that potential.

Two background items from our earlier work are important for this paper. First, when Kubo people expressed 'direction' they did so by reference to the flow of major waterways in the area where they lived and by reference to the point at which they were standing at the time. They did not refer to cardinal points. At Gwaimasi village, where we were based through those earlier years, 'up' and 'down' connoted flow direction of the Strickland River or, in some contexts, connoted a move between levee banks and back swamps. Sørum (n.d.) and Shaw and Shaw (1973) discuss this matter in some detail for the neighbouring language groups of Bedamuni and Samo. Secondly, when a Kubo person - male or female - explained where their land was they spoke of 'points' 
on the landscape; the junction of two streams, perhaps, or a cave (Minnegal and Dwyer 1999). They did not speak of borders, of 'lines' that separated the land of their clan from the land of someone from another clan. Their tenure system was 'zero dimensional' (Ingold 1986); association with and rights to land, a sense of ownership, declined with distance from a number of 'fixed' points. There was nothing akin to a clearly demarcated 'territory'. But the system was fluid. Maintaining rights to land also entailed on-going engagement with that land.

The present paper is based on research carried out for one month in NovemberDecember 2011 and for two months in December-January 2012-13. These visits to Suabi were undertaken to initiate a larger scale study of the ways in which the Liquefied Natural Gas project on neighbouring Febi land is contributing to epistemological and ontological changes among Kubo. In what follows we have used pseudonyms for the two men who showed us their maps and have spelled names as they did, including indicating vowel nasalization by adding an ' $n$ ' after the vowel. It is, perhaps, important to add that the sorts of changes we have previously reported for Kubo together with changes described hereafter are, in general terms, similar to changes that have occurred since colonization elsewhere in Papua New Guinea (e.g. Knauft 2002; LiPuma 2001; Strathern and Stewart 2004). It is simply that those changes have come late to Kubo. That difference, however, has given us the opportunity to observe and analyse changes on the ground and in the mind that occur before the outside world has intruded in any substantive ways. In a similar manner, Knauft (1996: 209-10) noted an innovative genre of séance among Gebusi that drew inspiration from 'a new set of tensions that seethed beyond the Gebusi horizon'. As with Kubo, they were responding to rumours and the expectations and desires rumours may create. And, where this occurs, as we have argued, it is clear that the people themselves are the primary agents of change (Dwyer and Minnegal 2007).

\section{MICHAEL'S MAP}

Michael's map was drawn in 2006 by a contact he had in the town of Kiunga $110 \mathrm{~km}$ west of Suabi (Fig. 2). It was prepared, on the basis of information Michael provided, as part of a Statutory Declaration that asserted that he was the leader of Huiyasoso Aedibi clan and that members of this clan were the 'rightful owners' of an area of land which included Suabi Mission Station and the Suabi airstrip. The map has been drawn on a standard template and the details shown at the bottom of Figure 2 state that it presents a 'schematic layout' prepared by West Maintenance Services Limited; these details have been removed from the copy of the map included in the Statutory Declaration. ${ }^{1}$ The Statutory Declaration has been signed by both Michael and a person acting as the 'Commissioner for Oaths' and carries an official stamp of the 'Papua New Guinea Commissioner for Oaths - Kiunga'. It is accompanied by a typed list of 86 purported members of Huiyasoso Aedibi clan. 


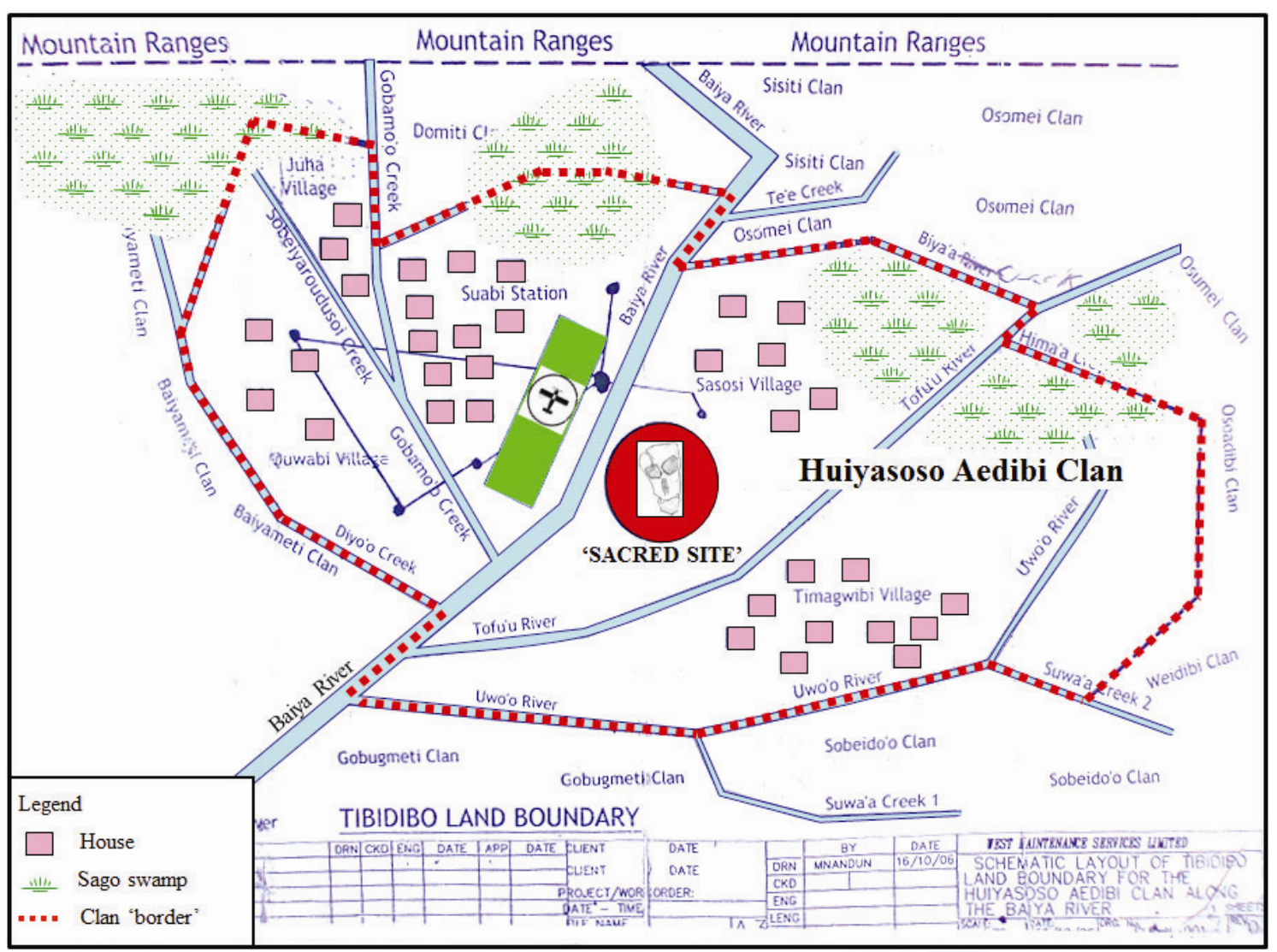

Fig. 2. Michael's map. For ease of reading we have highlighted, but not altered, primary features (streams, houses, sacred site, etc.) on the map, have overprinted some names and added a legend.

The map is centred on the airstrip at Suabi. It shows major rivers and streams, nearby swamps that are important for the production of sago, five clusters of houses named as Juha Village, Ouwabi Village, Suabi Station, Sasosi Village and Timagwibi Village - that comprise the greater community of Suabi and, near Sasosi Village, a 'sacred site' which is a rock that seems to carry the imprint of a human face. This rock is located within what was formerly a 'forbidden place' - a toin sa - where the spirits of deceased people associated with the surrounding land reside.

Michael's map demarcates a block of land named as Tibidibo. On the map this is enclosed by a dashed line that, for the most part, follows the path of a river and several streams commencing at the junction of Baiya and Uwo'o and, via the latter, to Suwa'a 2, Hima’a, Biya'a, Baiya, Gobamo’o, Diyo’o, Baiya and thence back to Uwo'o. It is this block of land that is declared to be owned by Huiyasoso Aidibi clan. It is less than 6 $\mathrm{km}^{2}$ and, presumably, represents all the land that Michael associates with that clan because it is shown as being contiguous with the lands of eight other clans.

In 2011 Michael and his wife and children had been living and working in Kiunga for at least five years. From time to time they visited Suabi. Sometimes Michael came alone; sometimes all the family came. When we first met him in December 2011, he introduced himself as 'papa bilong graun' - as the 'owner of the ground' - and immediately showed us his map and allowed us to photograph it. On the outside wall of 
a small, though unfinished, building that he had intended to be a trade store he displayed a painting that showed the same key features as the map (Fig. 3). People we spoke to from clans other than Michael's found the painting distasteful and disputed his assertions of ownership. Indeed, in 2011, Oil Search Ltd was paying K300 (approximately AUD\$150) a month to maintain an emergency fuel supply at the airstrip. This payment was distributed to members of three clans who had been judged to be 'land owners' by the local community. None of those clans was the clan to which Michael belonged.

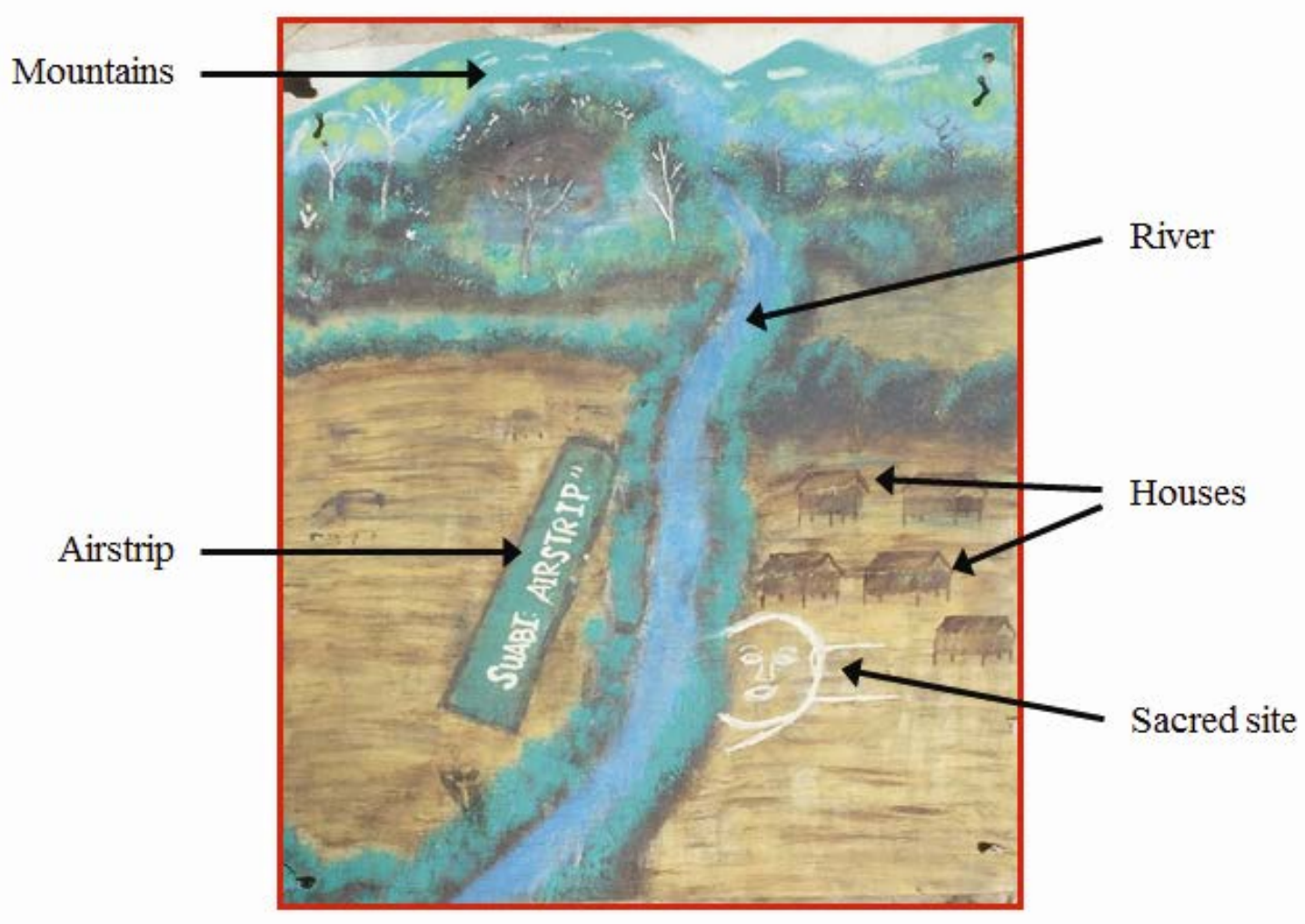

Fig. 3: Michael’s painting.

\section{PAUL'S MAP}

Paul's map was drawn with the assistance of a few other men in the latter half of the 2000s. We were shown it in November 2011 and allowed to photograph it (Fig. 4). Paul apologized for the fact that it was hand-drawn and did not include a 'legend'. Paul's affiliations were with Sisithy which, he told us, was a subclan of Nomo. 


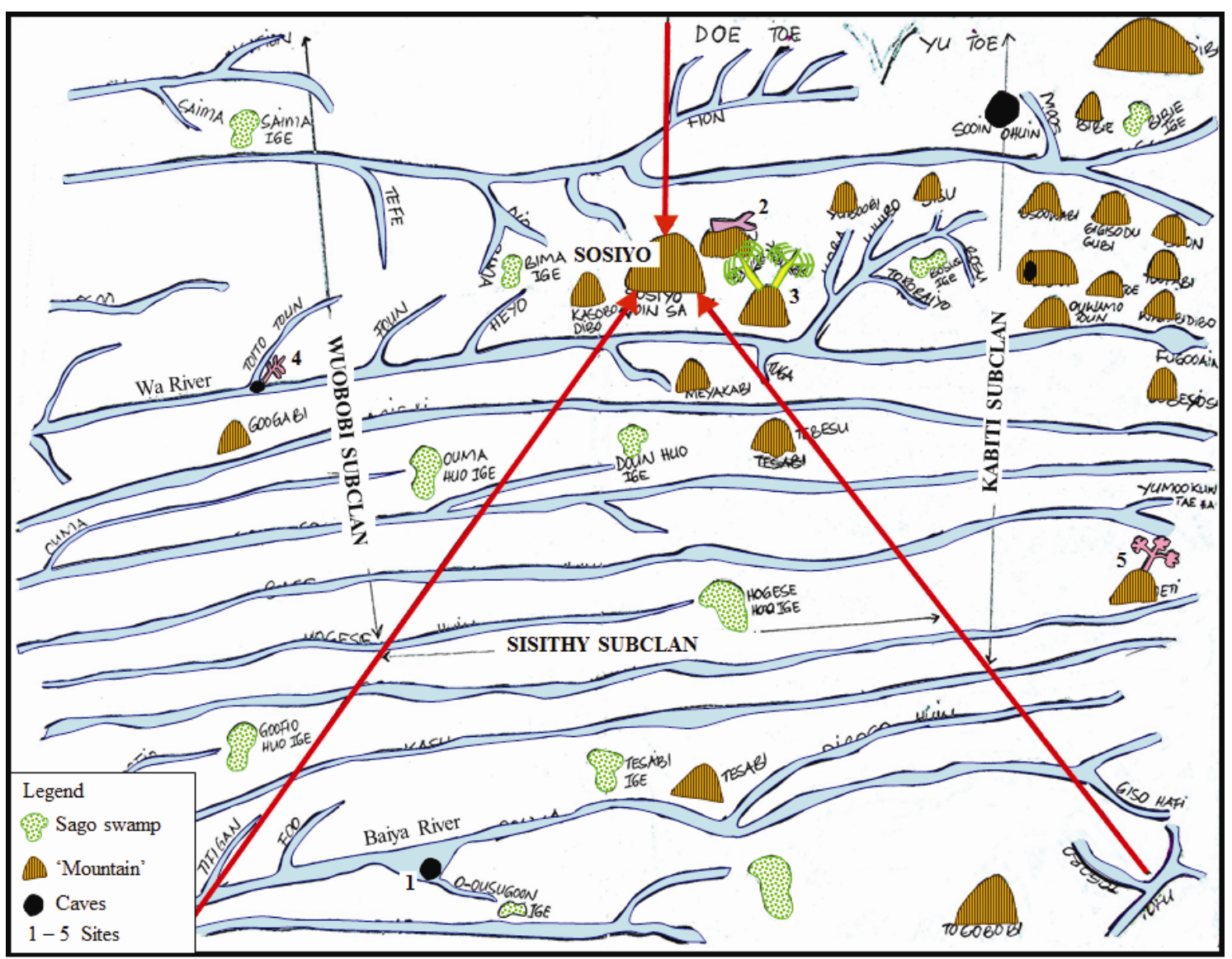

Fig. 4. Paul's map. For ease of reading we have highlighted, but not altered, primary features (streams, mountains, caves, etc.) on the map, have overprinted some names and added a legend.

The map depicts an area immediately to the east and north of the Suabi airstrip. It shows the primary river - Baiya - and many smaller, named, streams. The primary orientation of all these waterways on the map is from right to left (east to west). The map shows named sago swamps and mountains and unnamed caves. It features a cave from which pigs appeared in an origin story of Nomo clan (Site 1) and a mountain, Duwon Kabi, where trees are harvested to make high quality kundu drums (Site 2). It features another mountain, Tai Su, where there are palms that are ideal for making bows (tai) and which Suabi residents visit in attempts to get mobile telephone reception (Site 3). It also shows two other significant sites though we did not learn details concerning them (Sites 4 and 5).

Three arrows, drawn on the map, converge on a mountain (Sosiyo) where, for three named subclans within Nomo clan (Wuobobi, Sisithy and Kabiti), the spirits of the dead reside. 'It is a dangerous mountain', Paul told us. If you venture onto it then, emanating from its deepest recesses, you can hear the sounds of large trucks, of aeroplanes and of other paraphernalia of the West. You can hear the sounds of 'modernity' in an upside-down spiritual world that lies beneath the land of living Kubo people (cf. Knauft, 1998, on Gebusi accounts of an underground world where western goods and privileges could be accessed). 


\section{‘FABRICATING’ RECOGNITION}

In Papua New Guinea, people in many language groups have responded to the arrival of outsiders - missionaries, mining and timber company officers, bank managers, anthropologists and, less tangibly, the state or nation - by preparing their own documents: documents that, in their understanding, mimic the form and potential power of the documents held, compiled and regularly consulted by those outsiders. Cox (2011), for example, illustrates and analyses the role of paper documentation, modelled on the documents of financial and Christian institutions, in a Papua New Guinea fast money scheme. Bainton (2006), similarly, reveals the critical importance of locally produced documents by advocates of a 'Destiny Plan' on Lihir Island which outlined an imagined program for development at a time after the existing gold mine had completed operations. He noted that the plan 'drew on a stylised image of the West, largely gained from ... observations of the mining company' (2006: 248) while, at the same time, 'tapping a rich magico-religious vein' (2006: 248). Again, Jorgensen (1997: 611) reported that, in 1992, when, on behalf of Highlands Gold Ltd, he participated in a genealogical study among Telefolmin, some people asserted ownership rights by means of 'typescript statements or computer-generated census lists that made an excellent approximation of official village registers'. And, as a final illustration, in his report on a social mapping study among Febi, Ernst (2008: 54) included a map, drawn by a local man, that shows the location of sites of sacred significance relative to rivers, lakes, mountains and villages.

The production of these forms of documentation may be understood, as Jorgensen (2007: 58) has argued, as techniques through which local people seek to 'make themselves visible to the state', and to others such as mining companies, 'in a way that gives them some purchase on the ... decisions and operations' of the state and those others. They may be understood too as techniques through which particular groups of local people seek to position themselves favourably with respect to other, potentially competing, local groups. In Papua New Guinea, this is the case where local people have sought legal recognition for new forms of clan-based groupings as a means of asserting, or establishing, ownership of land and, hence, rights to royalties from extractive industries on that land (Bell 2009, Ernst 1999, Filer 2007, Gilberthorpe 2013, Guddemi 1997, Jorgensen 2007, Weiner 2007).

It was not till the mid-2000s, however, that Kubo people initiated such forms of documentation - 'family' or 'clan' membership lists, lists of office bearers for Incorporated Land Groups, and (often fabricated) references from previous employers. Relative to many other language groups in Papua New Guinea, their efforts in this direction have been remarkably recent; 15 or more years after others such as Duna and Telefomin had done the same (Jorgensen 1997, Strathern 1991). They did so, we argue, to accommodate their life-way to what they understood to be the expectations and practices of mining and logging companies and of the state. But, to 2012, with the single exception of Paul's statutory declaration, the documents they produced, and the committees they formed, had no legal standing. Kubo people had not registered a single ILG. Nor, in fact, had Paul taken any actions beyond asserting his ownership rights locally with respect to the statutory declaration that had been formally submitted six years earlier. 
At one level, therefore, the variety of documents that are being produced by Kubo people are 'fabrications' - political acts through which they strive for recognition but without a substantive appreciation of the legal requirements entailed in achieving such recognition. At this level, Kubo are, at present, 'talking to each other' as they prepare for a desired future. At another level, however, perhaps because they are such recent expressions - innovations with consequences for reshaping the architecture of the Kubo world but, as yet, without impacts on the outside world - it is the form, rather than the content, of those documents that is revealing. They strive to express new understandings. They do so by grappling with, and abstracting from, new observations and new experiences and, in this, they offer insight into the creativity entailed in social change. The maps produced by Michael and Paul are informative in this regard.

\section{ABSTRACTION AS OBJECT}

'Maps of meaning' ... are ideological instruments in the sense that they project a preferred reading of the material world, with prevailing social relations mirrored in the depiction of physical space. Some meanings are dominant; others result from struggle against the dominant order (Jackson 1989: 186).

Maps are always abstractions. They reduce information content; they are not the lived territory (Bateson 1979) though they both express and shape meaning. But, as abstractions, they may be valued differently. Thus, for example, Muehrcke (1996: 275) wrote that 'abstraction frees us from the tyranny of our physical existence' while Comaroff and Comaroff (1989) wrote, more pessimistically, of the 'violence of abstraction'.

Among Kubo, in the years 1986 to 1999, we knew of only two occasions when people drew maps. In 1995 a boy, about 11 years old, responded to our confusion concerning the whereabouts of a sago processing site by sketching the tracks we should take and the streams we should cross to find our way. Using his map we found the place. Again, later in the same year, a youth showed us a written record of a hunt in which he had participated. He had also drawn a map showing the layout of family houses at Gwaimasi - the village where we were based. Though the scale was seriously awry with respect to relative distances between houses, there was only one misplacement on his map; he located the house of one man alongside the house of that man's brother-in-law when this was not correct though, from our own earlier observations, this is where we would have expected that house to be located. In both these cases the maps were responses to our practices. We routinely mapped villages, gardens and forest tracks. From the time of our earliest stay among Kubo, people were interested in, commented on, and sometimes offered corrections to, the maps we had drawn. They learned quickly how to read the topographic maps that covered the area in which they lived.

Michael's and Paul's maps were motivated by very different considerations. They were drawn at a time when the Liquefied Natural Gas project was active on the land of their Febi neighbours to the north, when Kubo land and the airstrip at Suabi 
were being used as an operations base by the Company undertaking that project, and with some knowledge of social mapping and social impact studies among Febi and Huli people to the north and north-east (Ernst 2008, Goldman 2009). The Liquefied Natural Gas project provided both the intellectual and practical stimulus to produce and use maps. The maps were assertions of rights to land. They were political acts that gave expression to desires. But they expressed very different understandings of the always ambiguous notions of ‘ownership’ and ‘property’ (Filer 2007; Strang and Busse 2011).

Michael's map, though admittedly schematic, is inaccurate on several counts. It is certainly not oriented with north to the top - though, of course, that convention is irrelevant here. Rather, for better ground-truthing, north might be best oriented to $315^{\circ}$. More seriously, the cluster of houses labelled as Suabi Station should be shown to the east, and not to the north, of the airstrip. Further, neither the number of houses shown on the map, nor the proportion of the total shown in each cluster, reflects the facts on the ground. But these observations are trivial. The striking feature of the map - the feature of greatest importance to Michael - is the unambiguous boundary enclosing the land that Michael asserts is that of his clan. For anyone who knows, or can learn, the names of the waterways, that block of land is clearly defined by the dotted line on the map.

Paul's map is, objectively, less accurate than Michael's. The depiction of Baiya River and the sacred mountain Sosiyo suggest an approximate north-south orientation from top to bottom. But this is almost certainly coincidental. Further, the horizontal distance spanned at the bottom of the map is, in fact, considerably greater than the horizontal distance spanned at the top of the map. The major stream shown above, and running parallel to, Wa River is a tributary of Wa and the indicative 'box' on Figure 1 would be better drawn as a trapezoid. Of greater significance, however, is the fact that Paul has shown primary rivers and streams as flowing, in parallel, from right to left across the map. Finally, the three arrows converging on the 'forbidden place' are not representative of anything that outsiders could perceive on the ground. They may be best understood as tracing paths followed by spirits of the dead as they move to their final resting place. It is in these latter matters, in particular, that we may appreciate the distinct logical bases that inform the two maps.

Michael's map is informed by a digital logic that conforms to 'Western' practices and expectations. Irrespective of its empirical accuracy, or its acceptance by others, it unambiguously asserts that an identifiable, bounded area of land is associated with a purportedly identifiable aggregate of people. The 'area' and the 'group' might be challenged by others but at least they, and we, would know what and who were being challenged. Michael's map has little connection with past Kubo practices with respect to talking about or using land. It has appropriated conventional 'Western' notions of property and symbolized part of the Kubo landscape in accordance with those notions. It could, at least at first sight, easily satisfy the requirements of timber or mining companies who have legal obligations to compensate or pay royalties to those who 'own' the land that they wish to exploit. Both the land purportedly owned and, in the list accompanying the map, the owners of that land are rendered 'visible' for such purposes.

Paul's map is underlain by an analogical logic. On his map there are no borders that mark or separate clan, or subclan, territories. Instead, for three subclans of Nomo, 
the map gives a sense of both their spatial and spiritual relationships. And, further, though there is no concern with depicting boundaries there is a deep concern with identifying, and often naming, sites - sago swamps, mountains, caves and so forth. To Paul some of these sites are important for secular reasons (e.g. swamps where sago is produced) while others are important for sacred reasons (e.g. the mountain Sosiyo). Paul's map is faithful to Kubo socio-geographic understandings, at least as they were expressed a decade earlier (Minnegal and Dwyer 1999) and continued to be practiced in 2011, in ways that Michael's map is not. Its orientation with respect to space is dominated by showing primary waterways as parallel - 'all the rivers flow west' - and, thus, in accordance with conventional Kubo practices when talking about direction. ${ }^{2}$ And its emphasis is with sites; sites that locate people, their activities and their stories in relation to landscape and, indeed, in relation to each other rather than by reference to bounded areas. No lines or landscape features separate the three subclans of Nomo that are named on the map. Their lands and connections diffuse into each other and, ultimately, converge in the afterlife at the 'forbidden place'. In this case, then, it is relationships that are rendered 'visible', not the entities that they entangle.

Michael's map depicts what, in fact, was not the case or, at least, is not yet the case while Paul's map depicts what was once and, in many ways, is still the case. Both maps are, of course, abstractions. Michael's map is informed by an epistemology that gives emphasis to categorical distinctions, Paul's map is informed by a relational epistemology that highlights associations but avoids bounding either land or people. Yet both qualify as readings of landscapes that are experienced as thoroughly humanized (Dwyer 1996) and both 'entangle' the concrete and the abstract, the literal and the figurative. Michael highlights rivers and streams that are accessible to anyone who uses the map and a border that, to at least many Kubo people, is a figment of his imagination. Paul highlights sites that, with guidance, anyone can find and spirit tracks that, to outside observers, have no objective standing. Both maps are selective in what they do or do not record. Michael's map is unambiguously a statement of ownership; it is distanced from engagement. Paul's map is, much more, a statement of belonging, a statement of engagement with the land. Both maps offer ways for those who might use them to negotiate - or, potentially, lay claim to - the 'territories' or the sites that they depict. They model reality: Michael's reality, Paul's reality and the realities that others might bring to bear when reading the maps. They give expression to tropes that have been variously, and differently, drawn from the past and recent present. And they both do so with an eye to the future.

In an analysis of art, economics and sociality among Western Desert Australians from Balgo, Carty (2011) discusses the temporal trajectory of abstraction in acrylic painting. In one case study he shows how the styles of two artists - a husband and wife - diverged from an initial commonality of form and content, with one of the two maintaining form (iconography) while transforming content (narrative) and the other transforming form while maintaining content (2011: 263-301). The paintings of both artists expressed what had once been the case in different ways. Through invoking the 'figurative', and thus laying the foundations for refiguring the 'literal' (the 'concrete'), they expressed different realities. The 'objects' they created were 'abstractions' but that judgement can be made only by observers. It need not be - is likely not to be - the judgement of the practitioners. Indeed, as Carty noted, 'Balgo painters don't say they 
are making paintings of their country, they say they are painting "Country" or "My Country"' (2011: 10) and he quotes Biddle (2007: 102) who wrote that 'Country is not represented, it is materially made and manifest'. Abstraction as object is relative to both observer and practitioner. We cannot conclude for either the Western Desert couple, or for Michael and Paul, that either one of each pair would judge their own work by reference to its distance from experienced reality.

There is, however, a matter of scale here. Professional cartographers are necessarily aware that the maps they produce are 'representations'. This is the task for which they are contracted. As skilled practitioners they devote much effort to selfconsciously creating icons that stand for particular features of the landscapes or other 'scapes' that they depict. They provide legends that guide readers in the task of translating those icons and, indeed, perhaps Paul's apology that a 'legend' was missing from his map is indicative of the fact that he too was aware that that map was, at some level, an abstraction. We do not know, of course, what Paul would have shown in a 'legend'. But even where map-makers bring this awareness to bear on the task at hand, acknowledging that cartography combines art and science, they are much less likely to be aware of the degree of abstraction that is already entailed in the materials they draw on to make the map - aerial and satellite images, GPS readings, ground truthing and so forth. These materials index the reality wherein they dwell. As Wagner (2001: 71) suggests, the tale of how a map has been made is always part of that map.

Carty (2011: 295-96) argued that the differences between the paintings of the Balgo husband and wife were less important than the 'generalized process of abstraction taking place' and less important than the fact that, for both artists, the process was one 'in which social relationships are inextricable from the specific forms that appear on canvas'. The same is true of Michael's and Paul's maps and it is to the process of abstraction that we now turn.

\section{ABSTRACTION AS PROCESS}

Really new concepts, having no names in current language, always make their earliest appearance in metaphorical statements ... therefore the beginning of any theoretical structure is inevitably marked by fantastic inventions (Langer 1957: x-ix).

We had forgotten Langer's words when we first saw the maps. Michael's map was at once familiar to us; Paul's was more puzzling. Michael's map conveyed a sense of the familiar; Paul's was distanced from our recent experience - it was 'abstract'. But, of course, our immediate reactions were wrong.

Langer's words redirected our attention from the products to the process of abstraction. She directs attention to the perpetual flow of tropes that underwrite abstraction, to the manner in which the familiar sheds light on the unfamiliar in ways that ultimately, though often temporarily, rewrite experienced reality. She directs attention to tropes that accrete, concretize and ultimately dissolve as they reassemble in new ways (Dwyer 2005; Wagner 1972) to, ultimately, reshape the ways in which people think and live. And it is this process - the creative practices and outputs of individual 
people through time - that lies at the core of social change (Dwyer and Minnegal 2010). It is through this process that people come to know and act with landscape and other people in new ways. It may free them from a past that they now find tyrannical, it may be experienced as violence or, perhaps most often, it may be simply and unconsciously experienced as the ways things are or should be.

Each mark on a map is a representation of something real or imagined. Each mark on a map is, therefore, at some level, a trope. Paul's map is an abstraction. It has concretized the phenomenological. It has depicted the fluidity of lived, relational experience on paper and, thereby, commenced to fix it in both space and time. Michael's map takes the process of abstraction further to create new imaginaries, new realities, new truths that are more distanced from what was once the case. Abstraction is ever present. Through time the tropes that inform abstraction accrete in new ways to elicit 'fantastic inventions' and, ultimately, offer new theoretical understandings.

And, herein, lies a confusion; a confusion of product and process, of states of being with processes of becoming. When social change is represented as a shift from the more concrete to the more abstract - when, for example, the symbolic forms of a preliterate people are said to be concrete (e.g. Barth 1975) and their presumed capacity for abstraction is thereby diminished - that assertion is underlain by the epistemological arrogance of the 'West'. Explanation decays to description, the figurative decays to the literal, the abstract ultimately takes on the appearance of the concrete. The products of a categorical epistemology may - indeed do - differ from those of a relational epistemology, as the two maps illustrate, but the process entailed in the transformation of both is identical. It is universal. It is a process that creates new ways of living as it loses its hold on an earlier phenomenology. It is not the products of abstraction that, of themselves, should be seen in positive or negative light but, rather, the uses to which they may be put. They are always inextricably embedded in the social relationships from which they emerge and which they transform.

We are reminded of Pablo Picasso’s first visit to the Museum of Ethnology in Paris. That was in 1907. He was seeing 'objects of art' from Africa. He wrote:

A smell of mould and neglect caught me by the throat. I was so depressed that I would have chosen to leave immediately. But I forced myself to stay, to examine these masks, all these objects that people had created with a sacred, magical purpose, to serve as intermediaries between them and the unknown, hostile forces surrounding them, attempting in that way to overcome their fears by giving them colour and form. And then I understood what painting really meant. It's not an aesthetic process; it's a form of magic that interposes itself between us and the hostile universe, a means of seizing power by imposing a form on our terrors as well as on our desires. The day I understood that, I had found my path (in Meldrum 2006).

Picasso understood those 'objects' to be revelations of the world as experienced by both their creators and their intended audience. Like the paintings of Western Desert artists they expressed 'real' experience. And it was this that Picasso himself now wanted to capture. He wanted to reveal the true nature of that which he painted by removing 
elements that concealed and imprisoned it (cf. Ingold 2011: 206). It was only after that visit that, as he wrote, he understood what painting really meant, that he found his path. It was his attempt to depict real experience that others called 'abstract' art.

In his discussion of maps, representation and 'Native' Amazonians, Gow asks 'what sort of processes produce and depend on representations, and what sorts do not?' (1995: 44). He contrasts the knowledge ecologists bring to bear when seeing Amazonian forest with that of native Amazonians. For the former, he suggests, '[that] knowledge is essentially abstract, and produced by their own accumulation of records on paper in their scientific practice' (1995: 44). For the latter, '[that] knowledge is part of lived experience' (1995: 44). He argues that understandings of space and time generated by representations constitute the 'real world' for those who make them and for those who use them. They constitute an 'abstract order' that is thereafter imposed on other spaces and other times (1995: 60). Here, then, Gow is showing how the process of abstraction generates products that express meaning. It is this (always ephemeral) generation of meaning that is deeply enmeshed in the creative explorations of the lived worlds experienced by Michael, Paul and Picasso. Each of them depicted their experience on paper. They did so as acts of communication. In doing so, however, each of them 'represented' particular moments - particular experiences - as being different from all other moments. They punctuated their holistic experience through a process of abstraction that entailed some 'level of digitalization' (Wilden 1972: 403-04). The differences they created became the meanings they expressed.

As an 'object', abstraction is experienced as a distancing from lived experience. As a 'process' it transforms that experience and creates contexts for further transformation. Taken separately, the maps produced by Michael and Paul are abstract 'objects' that were intended to have political repercussions. Taken together, they provide insight into the process and, indeed, the trajectory of social change. As political actors, therefore, Michael and Paul have, to varying extents, adopted Western practices of representation; as imaginative beings their representations have tracked those of the West. At Suabi, it seems that, at least not long ago, all the rivers flowed west. But now, perhaps as always, it is all the tropes - it is abstraction itself - that flows in that direction. That flow, however, does not inevitably lead to the same destination. Invoking the figurative lays the foundations for refiguring the literal (the 'concrete'), but the entanglement of figure and ground renders all histories of change contingent.

\section{ACKNOWLEDGEMENTS}

We thank The University of Melbourne for granting research leave, the Papua New Guinea National Research Institute for affiliation and research visas, John Carty, Tom Covington and Anaïs Gérard for advice and everyone at Suabi for their hospitality, friendship and information. Our research has been supported by an Australian Research Council Discovery Grant (DP120102162). 


\section{NOTES}

1. West Maintenance Services Limited is a Kiunga-based, locally owned construction company where Michael has been employed since the mid-2000s.

2. A person walking from Suabi to Tai Su to cut bow blanks or access mobile telephone reception would cross seven major streams. At each crossing place he or she would be facing forwards and the flow of water would be always to his or her left. Relative to his or her orientation at these places, the streams would be parallel to one another.

\section{REFERENCES}

Bainton, N. A. 2006. Virtuous Sociality and Other Fantasies: Pursuing Mining, Capital and Cultural continuity in Lihir, Papua New Guinea. Unpublished PhD thesis, The University of Melbourne.

Barth, F. 1975. Ritual and Knowledge among the Baktaman of New Guinea. New Haven: Yale University Press.

Bateson, G. 1979. Mind and Nature: A Necessary Unity. New York: E.P. Dutton.

Bell, J. A. 2009. Documenting discontent: struggles for recognition in the Purari Delta of Papua New Guinea. The Australian Journal of Anthropology 20: 28-47.

Biddle, J. L. 2007. Breasts, Bodies, Canvas: Central Desert Art as Experience. Sydney: University of New South Wales Press.

Carty, J. 2011. Creating Country: Abstraction, Economics and the Social Life of Style in Balgo Art. Unpublished PhD thesis, Australian National University.

Comaroff, J., Comaroff, JL. 1999. Occult economies and the violence of abstraction: notes from the South African postcolony. American Ethnologist 26(2): 279-303.

Cox, J. C. N. 2011. Deception and Disillusionment: Fast Money Schemes in Papua New Guinea. Unpublished PhD Thesis, The University of Melbourne.

Dwyer, P. D. 1996. The invention of nature. In R. Ellen, K. Fukui (eds) Redefining Nature: Ecology, Culture and Domestication, pp. 157-86. Oxford: Berg.

Dwyer, P. D. 2005. Ethnoclassification, ethnoecology and the imagination. Journal de la Société des Océanistes 120-121: 11-25.

Dwyer, P. D., Minnegal, M. 1992. Ecology and community dynamics of Kubo people, in the tropical lowlands of Papua New Guinea. Human Ecology 20(1): 21-55.

Dwyer, P. D., Minnegal, M. 1998. Waiting for company: ethos and environment among Kubo of Papua New Guinea. Journal of the Royal Anthropological Institute 4: 23-42. 
Dwyer, P. D., Minnegal, M. 2007. Social change and agency among Kubo of Papua New Guinea. Journal of the Royal Anthropological Institute (N.S.) 13: 545-62.

Dwyer, P. D., Minnegal, M. 2010. Theorizing social change. Journal of the Royal Anthropological Institute 16(3): 629-45.

Ernst, T. M. 1999. Land, stories, and resources: discourse and entification in Onabasulu modernity. American Anthropologist 101: 88-97.

Ernst, T. 2008. Full-scale Social Mapping and Landowner Identification Study of PRL02. Report to ExxonMobil Corporation, Papua New Guinea Liquefied Natural Gas Project.

Filer, C. 2007. Local custom and the art of land group boundary maintenance in Papua New Guinea. In J. F. Weiner, K. Glaskin (eds) Customary Land Tenure and Registration in Australia and Papua New Guinea: Anthropological Perspectives, pp. 135-73. Canberra: ANU E Press.

Giddens, A. 1990. The Consequences of Modernity. Cambridge, UK: Polity Press.

Gilberthorpe, E. 2013. In the shadow of industry: a study of culturization in Papua New Guinea. Journal of the Royal Anthropological Institute (N.S.) 19: 261-78.

Goldman, L. 2009. Papua New Guinea Liquefied Natural Gas Project social impact assessment 2008. http://www.pnglng.com/media/pdfs/environment/ eis_appendix26.pdf. [Accessed 3 April 2012]

Gouy, J., Kapa, J., Mokae, A., Levantis, T. 2010. Parting with the past: is Papua New Guinea poised to begin a new chapter towards development? Pacific Economic Bulletin 25(1): 1-23.

Gow, P. (1995) Land, people and paper in western Amazonia. In E. Hirsch, M. O'Hanlon (eds). The Anthropology of Landscape: Perspective of Place and Space, pp. 43-62. Oxford: Clarendon.

Guddemi, P. 1997. Continuities, contexts, complexities, and transformations: local land concepts of a Sepik people affected by mining exploration. Anthropological Forum 7: 629-48.

Hornborg, A. 1996. Ecology as semiotics: outlines of a contextualist paradigm for human ecology. In P. Descola, G. Pálsson (eds) Nature and Society: Anthropological Perspectives, pp. 45-62. London: Routledge.

Hydrocarbons-technology.com. 2012. PNG Liquefied Natural Gas (LNG) Project, Papua New Guinea. http://www.hydrocarbons-technology.com. [Accessed 21 July 2013]

Ingold, T. 1986. Territoriality and tenure: the appropriation of space in hunting and gathering societies. In T. Ingold (ed.) The Appropriation of Nature: Essays on 
Human Ecology and Social Relations pp. 130-64. Manchester: Manchester University Press.

Ingold, T. 2011. Being Alive: Essays on Movement, Knowledge, and Description. Abington: Routledge.

Jackson, P. 1989. Maps of Meaning. London: Routledge.

Jorgensen, D. 1997. Who or what is a landowner?: mythology and marking the ground in a Papua New Guinea Mining Project. Anthropological Forum 7: 599-627.

Jorgensen, D. 2007. Clan-finding, clan-making and the politics of identity in a Papua New Guinea mining project. In J. F. Weiner, K. Glaskin (eds) Customary Land Tenure and Registration in Australia and Papua New Guinea: Anthropological Perspectives, pp. 57-72. The Australian National University E Press, Canberra.

Knauft, B. M. 1996. Genealogies for the Present in Cultural Anthropology. New York: Routledge.

Knauft, B. M. 1998. How the world turns upside down: changing geographies of power and spiritual influence among the Gebusi. In L. R. Goldman, C. Ballard (eds) Fluid Ontologies: Myth, Ritual and Philosophy in the Highlands of Papua New Guinea, pp. 143-61. London: Bergin \& Garvey.

Knauft, B. M. 2002. Exchanging the Past: A Rainforest World of Before and After. Chicago: The University of Chicago Press.

Langer, S. K. 1957. Philosophy in a New Key: A Study in the Symbolism of Reason, Rite and Art ( $3^{\text {rd }}$ edition). Cambridge, M.A.: Harvard University Press.

LiPuma, E. 2001. Encompassing Others: The Magic of Modernity in Melanesia. Ann Arbor: The University of Michigan Press.

McIlraith, J., Robinson, S., Pyrambone, L. L., Petai, L., Sinebare, D., Maiap, S. 2012. The community good: examining the influence of the PNG LNG Project in the Hela Region of Papua New Guinea. Dunedin, NZ: University of Otago.

Meldrum, A. 2006. Stealing beauty. The Guardian 15 March 2006.

Minnegal, M., Dwyer, P. D. 1997. Women, pigs, God and evolution: social and economic change among Kubo people of Papua New Guinea. Oceania 68: 4760.

Minnegal, M., Dwyer, P. D. 1999. Re-reading relationships: changing constructions of identity among Kubo of Papua New Guinea. Ethnology 38 (1): 59-80.

Muehrcke, P. C. 1996. The logic of map design. In C. H. Wood, C. P. Keller (eds.) Cartographic Design: Theoretical and Practical Perspectives. New York: John Wiley \& Sons, pp. 271-78. 
Shaw, R. D., Shaw, K. A. 1973. Location: a linguistic and cultural focus in Samo. Kivung 6:158-172.

Sørum, A. (nd.) The Forked Branch: A Study of Meaning in Bedamini Ceremonial. Unpublished manuscript.

Stead, V. 2012. Embedded in the land: customary social relations and practices of resilience in an East Timorese community. The Australian Journal of Anthropology 23: 229-47.

Strang, V., Busse, M. 2011. (eds) Appropriation and Ownership. ASA Monographs 47. Oxford: Berg.

Strathern, A. 1991. "Company” in Kopiago. In A. Pawley (ed) Man and a Half. Essays in Pacific Anthropology and Ethnobiology in Honour of Ralph Bulmer, pp. 61215. Auckland: The Polynesian Society.

Strathern, A., Stewart, P. J. 2004. Empowering the Past, Confronting the Future: the Duna people of Papua New Guinea. New York: Palgrave Macmillan.

Wagner, R. 1972. Habu: The Innovation of Meaning in Daribi Religion. Chicago: The University of Chicago Press.

Wagner, R. 1977. Scientific and indigenous Papuan conceptualizations of the innate: a semiotic critique of the ecological perspective. In T. Bayliss-Smith, R. Feachem (eds) Subsistence and Survival: Rural Ecology in the Pacific, pp. 385-410. London: Academic Press.

Wagner, R. 2001. Condensed mapping: myths and the folding of space / space and the folding of myth. In A. Rumsey, J. Weiner (eds) Emplaced Myth: Space, Narrative, and Knowledge in Aboriginal Australia and Papua New Guinea, pp. 71-8. Honolulu: University of Hawai'i Press.

Weiner, J. F. 2007. The Foi Incorporated Land Group: group definition and collective action in the Kutubu Oil Project area, Papua New Guinea. In J. F. Weiner, K. Glaskin (eds) Customary Land Tenure and Registration in Australia and Papua New Guinea: Anthropological Perspectives. Asia-Pacific Environment Monograph 3, pp. 117-34. The Australian National University E Press, Canberra.

Wilden, A. 1972. System and Structure: Essays in Communication and Exchange. London: Tavistock Press. 


\section{University Library}

\section{- M M N E R VA A gateway to Melbourne's research publications}

Minerva Access is the Institutional Repository of The University of Melbourne

Author/s:

Dwyer, PD;Minnegal, M

Title:

Where all the rivers flow west: Maps, abstraction and change in the Papua New Guinea lowlands

Date:

2014-01-01

Citation:

Dwyer, P. D. \& Minnegal, M. (2014). Where all the rivers flow west: Maps, abstraction and change in the Papua New Guinea lowlands. Australian Journal of Anthropology (The), 25 (1), pp.37-53. https://doi.org/10.1111/taja.12071.

Persistent Link:

http://hdl.handle.net/11343/56363 